\title{
Postoperative epidural analgesia: is it worth the effort?
}

\author{
Richard C. Etches MD FRCPC
}

Postoperative epidural analgesia with opioids and/or local anaesthetics is advocated by some as the method of choice for selected patient groups. However, the evidence supporting these claims is confusing and incomplete. This lecture considers the question: Does epidural analgesia offer anything that cannot be accomplished with parenteral opioid analgesia?

The following discussion reviews the recent literature comparing epidural with parenteral analgesia in the adult postoperative patient, excluding obstetrics, as it pertains to the quality of analgesia, outcome, and cost of hospitalization. Unfortunately, few published reports address the three issues adequately, and there are many problems in interpreting and comparing the data. These problems include:

1 Small sample size and a consequent lack of statistical power.

2 Most papers focus on the quality of analgesia and associated side effects during the first one or two postoperative days, but do not consider late morbidity or overall cost of hospitalization.

3 Comparison of the existing studies is confounded because "epidural analgesia" refers to many different techniques. These include the use of different opioids with very different pharmacokinetic behaviour, the use of local anaesthetics with or without opioids, and the increasing use of adjunctive medication, especially nonsteroidal anti-inflammatory drugs (NSAIDs).

4 Techniques may be "effective", but too complex and/ or labour-intensive for routine application.

5 Finally, few studies compare epidural techniques with the best practical alternative - in most situations this implies intravenous patient-controlled analgesia ( $i v$ PCA), often in the context of "balanced analgesia" with local anaesthetic infiltration of the surgical incision and/or adjunctive medication such as NSAIDs.

\section{Review of the literature}

\section{Do epidurals provide better analgesia?}

MORPHINE

Although epidural morphine has been widely used since the early 1980s, few papers have compared the analgesic efficacy of epidural versus parenteral morphine, and all have serious methodological flaws. The most common problem is the failure to titrate adequately parenteral and/ or epidural morphine doses to effect. Despite this and other methodological problems, there is good evidence that epidural morphine provides superior analgesia after thoracotomy or major abdominal surgery. Shulman et $a l .{ }^{\prime}$ in a randomized, double-blinded study compared morphine $5 \mathrm{mg}$ administered epidurally or intravenously during and after thoracotomy. The study drug was administered on demand, but with at least $30 \mathrm{~min}$ between doses. Analgesia at rest was better for those patients receiving epidural morphine for the $24 \mathrm{hr}$ of the study. Unfortunately patients received only a single $5 \mathrm{mg}$ dose of morphine perioperatively, given prior to surgery. Therefore it is not surprising that patients in the im group had severe pain in the early postoperative period. In a similar patient population Miguel and Hubbell ${ }^{2}$ have shown similar results comparing epidural morphine with morphine 2-4 mg iv prn.

Two other randomized, prospective, but unblinded studies comparing im with epidural morphine following major abdominal surgery demonstrate conflicting results. Jayr $e t$ al. ${ }^{3}$ found considerably better analgesia with epidural morphine only on the first postoperative day; however, the dose of epidural morphine was very small, 2 $\mathrm{mg}$ q12h. Hjortso et al. ${ }^{4}$ using a dose of $4 \mathrm{mg} \mathrm{q12h}$, demonstrated better analgesia (presented as "cumulative pain" over the entire study period) with epidural versus im morphine over the three days of the study; this study is open to criticism because the im dose was relatively

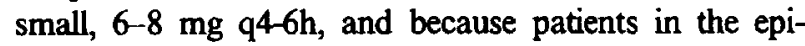
dural group received bupivacaine $0.5 \% 5 \mathrm{ml}$ q4h for the first $24 \mathrm{hr}$ after surgery. Cullen $e t$ al., ${ }^{5}$ in a randomized, double-blinded study comparing an epidural morphine infusion with im narcotics demonstated superior analgesia with epidural morphine. This study can be faulted because of the conservative doses of im morphine administered and because of the upper limit of $0.6 \mathrm{mg} \cdot \mathrm{hr}^{-1}$ epidural morphine.

From the Department of Anaesthesia, University of Alberta Hospitals, Edmonton, Alberta. 
The author has been able to find only one study comparing epidural morphine with intravenous PCA morphine. Kilbride et al. ${ }^{6}$ randomized patients undergoing major colorectal surgery to receive im, PCA, or epidural morphine. Those patients receiving epidural morphine $0.07 \mathrm{mg} \cdot \mathrm{kg}^{-1}$ "on a regular basis" had consistently better analgesia than those receiving im or PCA iv morphine for the duration of the study, approximately five days. Patients receiving epidural morphine used approximately $25 \%$ as much morphine as those receiving PCA morphine $i v$. Unlike the other studies cited, the use of $\dot{v}$ PCA with a bolus of $2 \mathrm{mg}$ and a background infusion of $2 \mathrm{mg} \cdot \mathrm{hr}^{-1}$ provides a practical method of ensuring that the patient can receive adequate parenteral therapy. Nor is this study confounded by the use of parenteral opioid therapy for breakthrough analgesia. As a result, this study provides some of the best evidence to date that epidural morphine provides better analgesia than parenteral morphine when both are titrated to effect.

\section{FENTANYL}

Just as morphine is the prototypical hydrophilic opioid for epidural use, fentanyl is the prototypical drug, and the most studied, among the lipophilic agents. In part because of the often stated opinion (not supported by the available data) that epidural fentanyl is less likely than morphine to cause dangerous respiratory depression, it is the epidural opioid of choice for some physicians.

Most of the studies comparing epidural with intravenous fentanyl can be assigned to one of three general designs; lumbar epidural fentanyl for lower abdominal or lower limb procedures, lumbar epidural fentanyl for thoracotomies, or thoracic epidural fentanyl for thoracotomies. In all of these studies, particular attention must be paid to the methods used to titrate fentanyl provided. Several studies adjust the fentanyl infusion (epidural or intravenous) until the patient reports a VAS pain score of less than 30 (out of 100); if this design is employed, it is expected that pain scores will be similar between groups. These studies are useful for demonstrating differences in fentanyl requirements, but do not adequately compare analgesic efficacy.

There is little evidence to support the use of lumbar epidural fentanyl for postoperative analgesia. In patients undergoing lower abdominal or lower limb surgery, there are no reported differences in fentanyl requirements, analgesia, or side effects when comparing epidural with $i v$ administration. ${ }^{7,8}$ Studies comparing lumbar epidural with $\dot{v}$ fentanyl for analgesia after thoracotomy yield similar results. Baxter et al. ${ }^{9}$ provided lumbar epidural or intravenous fentanyl at a fixed rate of $1 \mu \mathrm{g} \cdot \mathrm{kg}^{-1} \cdot \mathrm{hr}^{-1}$ following thoracotomy, with PCA morphine for supple- mental analgesia; there was no overall difference in pain scores or in the amount of supplemental morphine required. When the rate of lumbar epidural or iv fentanyl administration is adjusted to maintain a VAS pain score less than $30 / 100$, others report no difference in analgesia and no reduction in epidural, compared to intravenous, fentanyl requirements. ${ }^{10,11}$ Grant et al., ${ }^{12}$ comparing PCA fentanyl administered epidurally or $\dot{N}$, found no differences in analgesia, but did report a modest (28\%) decrease in fentanyl requirements in the epidural group.

Following thoracotomy or upper abdominal surgery, the value of thoracic epidural fentanyl is still uncertain. Welchew and Breen ${ }^{13}$ compared PCA fentanyl administered via a $\mathrm{T}_{7-8}$ epidural or iv after upper abdominal surgery; they demonstrated a $50 \%$ reduction in fentanyl requirements but no difference in pain scores. Salomaki et al. ${ }^{4}$ have reported similar results following thoracotomy with a $\mathrm{T}_{4-5}$ epidural fentanyl infusion - comparable analgesia with a $43 \%$ decrease in fentanyl requirements. Others have found no difference in pain scores and no lasting reduction in fentanyl requirements comparing thoracic to lumbar epidural or intravenous fentanyl; ${ }^{10,15}$ it is difficult to reconcile these results with those cited above. In contrast to the preceding papers, Benzon et al. ${ }^{16}$ did show better analgesia, particularly with coughing, following thoracotomy when patients received thoracic epidural fentanyl instead of iv PCA morphine. It is not clear why thoracic epidural fentanyl should be better than iv PCA morphine, but the same as iv fentanyl. Nor is it clear why some but not all reports demonstrate a reduction in the dose of fentanyl required when administered via the thoracic epidural compared to the intravenous route. Even if the overall quality of analgesia is similar, the incidence and severity of some side effects, including nausea and vomiting, ${ }^{10,13,14}$ sedation, ${ }^{10,14-16}$ and respiratory depression ${ }^{15}$ may be reduced when fentanyl is administered via the thoracic epidural route.

\section{ROLE OF BUPIVACAINE}

Epidural opioids alone can provide excellent analgesia, but are associated with important side effects. Similarly, epidural local anaesthetics can provide complete analgesia, but commonly cause an unacceptable incidence of motor, sensory, and autonomic blockade. The combination of low concentrations of bupivacaine with epidural opioids represents an attempt to minimize the side effects of both while maintaining the best possible analgesia. To date, however, the evidence is inconclusive.

Compared with parenteral morphine, thoracic $\left(T_{7}-T_{11}\right)$ epidural morphine $0.25 \mathrm{mg} \cdot \mathrm{hr}^{-1}$ with bupivacaine $0.125 \% 10 \mathrm{ml} \cdot \mathrm{hr}^{-1}$ was found to provide superior analgesia for at least $\mathbf{4 8} \mathrm{hr}$ following major abdominal surgery. However, seven of 78 patients had some degree of motor 
blockade on the first postoperative day. ${ }^{17}$ Moiniche et al. ${ }^{18}$ report similar results with morphine $0.2 \mathrm{mg} \cdot \mathrm{hr}^{-1}$ with bupivacaine $0.25 \% 4 \mathrm{ml} \cdot \mathrm{hr}^{-1}$ in patients undergoing open cholecystectomy via a mini-laparotomy; pain scores at rest and with activity were lower $24 \mathrm{hr}$ after surgery, but not $48 \mathrm{hr}$ after surgery. Unlike the former study, no patient had any detectable sensory or motor blockade at $24 \mathrm{hr}$.

Compared with epidural morphine alone, epidural morphine with bupivacaine may provide superior analgesia. Following major abdominal surgery, Bisgaard $e t$ al. ${ }^{19}$ administered either epidural morphine 4-6 mg q6$8 \mathrm{~h}$ or epidural morphine $0.54 \mathrm{mg} \cdot \mathrm{hr}^{-1}$ plus bupivacaine $0.25 \% 9 \mathrm{ml} \cdot \mathrm{hr}^{-1}$. Analgesia was better among those patients receiving morphine/bupivacaine during the first 16 $\mathrm{hr}$ following surgery, but these differences disappeared by $24 \mathrm{hr}$, with very low pain scores in both groups. Unfortunately, the authors did not mention the degree of sensory or motor blockade. In a similar study, Dahl et al. ${ }^{20}$ compared epidural morphine $0.2 \mathrm{mg} \cdot \mathrm{hr}^{-1}$ with or without bupivacaine $0.25 \% 4 \mathrm{ml} \cdot \mathrm{hr}^{-1}$. All patients received piroxicam preoperatively and postoperatively, and all patients received iv or im morphine as required. $\mathrm{Pa}$ tients who received epidural morphine with bupivacaine reported lower pain scores with rest and with activity for the first $30 \mathrm{hr}$ following surgery, but not at $48 \mathrm{hr}$. All patients receiving bupivacaine reported sensory blockade $48 \mathrm{hr}$ postoperatively but, no patient reported motor blockade $12 \mathrm{hr}$ postoperatively. In contrast, Logas et al., ${ }^{21}$ in a well-blinded, randomized, prospective study, found no advantage to adding bupivacaine $0.1 \%$ to thoracic epidural morphine $0.1 \%$ following thoracotomy. However, in both groups the analgesia was superior to that provided by morphine $i m$.

For epidural fentanyl with added bupivacaine $0.125-0.25 \%$, compared with fentanyl alone, the data are no more conclusive. Several studies demonstrate a modest reduction in pain scores and/or epidural fentanyl or supplemental parenteral opioid administration during the first $24 \mathrm{hr}$ after surgery, but these differences have not been demonstrated beyond the first postoperative day. Comparing thoracic epidural fentanyl $10 \mu \mathrm{g} \cdot \mathrm{ml}^{-1}$ with or without bupivacaine $0.2 \%$ following abdominal aortic surgery, George et al. ${ }^{22}$ demonstrated an $11 \%$ reduction in fentanyl consumption and lower pain scores among the patients receiving bupivacaine. One of ten patients receiving the fentanyl/bupivacaine mixture reported limb weakness. Because this study concluded $24 \mathrm{hr}$ postoperatively, it is not known if the differences in analgesia and drug consumption would be maintained. Using an identical protocol following thoracotomy, the same group demonstrated superior analgesia with the addition of bupivacaine for the first $18 \mathrm{hr}$, but not from 24 to $48 \mathrm{hr}$ postoperatively. As in the previous study, one of ten patients reported limb weakness. ${ }^{23}$

Badner et al. ${ }^{24,25}$ reported that the addition of bupivacaine $0.125 \%$, but not $0.1 \%$, to epidural fentanyl improved analgesia during the first $48 \mathrm{hr}$ following surgery. Fentanyl requirements did not differ between groups. However, the difference in pain scores was greatest in the recovery room. This may be explained, at least in part, by the fact that patients receiving the bupivacaine/ fentanyl mixture received almost twice as much bupivacaine intraoperatively. If one excludes the recovery room pain scores from the analysis, there is no difference between groups. In addition, of the 13 patients who received bupivacaine $0.125 \%$, four developed motor weakness, and three had areas of numbness.

Following orthopaedic surgery, the addition of bupivacaine $0.1 \%$ to epidural fentanyl did not improve analgesia or reduce fentanyl requirements. ${ }^{26}$ In contrast, the addition of bupivacaine $0.125 \%$ to patient-controlled epidural fentanyl $5 \mu \mathrm{g} \cdot \mathrm{ml}^{-1}$ did reduce fentanyl requirements by $24 \%$; again, pain scores were similar between groups. However, this fentanyl-sparing effect was offset by an increased incidence (48\%) of hypotension. ${ }^{27}$

Most recently, in a well-controlled, randomized, double-blind study, Benzon et al. ${ }^{28}$ compared epidural fentanyl $10 \mu \mathrm{g} \cdot \mathrm{ml}^{-1}$ alone, or with bupivacaine $0.1,0.15$, or $0.2 \%$ in patients undergoing major abdominal or genitourinary surgery. The authors found no difference in analgesia at rest or with coughing and no difference in fentanyl consumption. More patients in the bupivacaine groups reported segmental numbness; otherwise side effects were similar between groups.

Particularly with epidural fentanyl, alone or with bupivacaine, it is difficult to explain the differing results, but several factors may play a role. First, few studies allow the patients themselves to titrate the dose of epidural medication. More commonly, the investigator provides an infusion at a fixed rate or titrated to a particular VAS pain score, usually $3 / 10$ or less. Secondly, fentanyl with or without bupivacaine, may be more effective when used to treat the pain associated with a surgical incision at a single dermatomal level (i.e., a thoracotomy or subcostal incision, rather than a vertical abdominal incision or abdomino-perineal procedure). Lastly, few studies record pain scores with activity; these may be more discriminating than pain scores at rest.

To summarize, studies undertaken in the last ten years support the argument that epidural morphine provides analgesia superior to that obtained with im or iv PCA morphine following major abdominal or thoracic surgery. For fentanyl, the evidence is not convincing. However, it is clear that if one does choose epidural fentanyl, the epidural should be located at the same dermatomal level 
as the surgery. For epidural fentanyl and morphine, the addition of bupivacaine $0.125-0.25 \%$ may improve analgesia and reduce opioid requirements during the first 24 hr postoperatively. Beyond that period, there are few data to support its use. The addition of bupivacaine $0.1-0.25 \%$ to epidural opioids results in excessive motor, sensory, and autonomic blockade in some patients. These side effects are potentially serious if they limit mobility, mask symptoms, or result in relative hypovolaemia with hypotension and/or low urine output.

\section{Do epidurals improve outcome?}

There is general agreement that epidural opioids, with or without the addition of bupivacaine, can provide postoperative analgesia as good as and often better than that provided by parenteral opioids. There is, however, much less consensus on whether or not epidural opioids are associated with an improved outcome. This lack of consensus is due in large part to the limitations imposed by study design. Many studies comparing parenteral with epidural opioids are of short duration, often $24-48 \mathrm{hr}$, and focus primarily on analgesia and opioid requirements. Some studies use a fixed dose of epidural opioid, often with parenteral opioids for supplemental analgesia. Few studies allow the patient to determine the dose of epidural opioid received; more commonly, the investigator adjusts the opioid infusion rate to obtain a VAS pain score of less than $3 / 10$. Few studies focus on high-risk patient populations. If one considers only those studies which address these concerns, then the evidence favouring epidural analgesia is much more persuasive.

Three randomized, prospective studies show beneficial effects associated with epidural analgesia after major surgery. In their landmark paper, Yeager et al. ${ }^{29}$ randomized high-risk surgical patients (defined as patients scheduled preoperatively for postoperative ICU admission) to receive either general anaesthesia with parenteral opioid analgesia postoperatively, or epidural anaesthesia with "light" general anaesthesia followed by epidural analgesia with local anaesthesia and/or opioids. This study was terminated after only 53 patients because of the markedly lower incidence of cardiovascular morbidity, major infections, and overall complication rate. Mortality was also lower among patients receiving epidural analgesia, but because of the small sample size, the authors chose not to emphasize this finding.

Tuman $e t$ al. ${ }^{30}$ have since repeated Yeager's study using a similar methodology in 80 patients undergoing major vascular surgery, including infrainguinal (55\%) and aortoiliac $(45 \%)$ procedures. Patients randomized to the epidural group were older, and had a greater incidence of diabetes and previous myocardial infarction preoperatively. On several other variables, including history of angina, congestive heart failure, renal dysfunction, the preoperative incidence among patients receiving epidural analgesia was higher, although not statistically significant. Like Yeager's study, Tuman et al. found a lower complication rate, in particular fewer cardiovascular and infectious complications, and fewer graft occlusions. The incidence of neurological complications and prolonged tracheal intubation was also less, approaching statistical significance, among patients receiving epidural analgesia. Using logistic regression analysis, the only predictors of cardiovascular complications were a history of congestive heart failure and general anaesthesia without an epidural. The higher incidence of graft occlusion reported in this study has also been demonstrated in a study of patients undergoing infrainguinal vascular surgery with either general anaesthesia and parenteral analgesia or epidural anaesthesia and epidural analgesia for approximately 24 hr postoperatively. ${ }^{31}$

From the studies cited above, it is possible that the differences in morbidity were due to the anaesthetic technique, rather than the postoperative analgesia. To address this question, Baron et al. ${ }^{32}$ studied 173 patients scheduled to undergo abdominal aortic surgery. Patients were randomly assigned to receive either general anaesthesia alone, or $\mathbf{T}_{8-9}$ epidural anaesthesia with "light" general anaesthesia. Postoperatively, patients in both groups received either $s c$ morphine, epidural bupivacaine, or epidural fentanyl. In patients receiving epidural anaesthesia tracheal extubation was sooner (five versus eight hours) after surgery, but there were no other differences in clinical outcome. The authors concluded that a combined general-epidural anaesthetic is of no advantage compared with general anaesthesia alone, and that postoperative analgesia, rather than perioperative management may be the more important determinant of outcome.

In contrast to the studies of Yeager and Tuman, Hjortso et al. ${ }^{4}$. found no difference in outcome in a study of 100 patients undergoing major abdominal surgery when comparing parenteral morphine with epidural morphine. However, Hjortso et al. excluded patients undergoing vascular and thoracic procedures and, in contrast to the studies of Yeager and Tuman, the incidence of severe preoperative cardiovascular and respiratory disease was low - almost all patients were classed as ASA 1 or 2. Other studies purporting to show us benefit from epidural analgesia have other methodological limitations, in particular dose or duration of epidural opioid analgesia. Jayr et al. ${ }^{3,17}$ demonstrated no benefit from epidural analgesia following major abdominal (non-vascular) surgery; however, patients received relatively small, fixed doses of epidural morphine $\left(0.2-0.25 \mathrm{mg} \cdot \mathrm{hr}^{-1}\right)$. In a study of 50 patients undergoing abdominal aortic surgery, Davies et al. ${ }^{33}$ found no difference in postoperative mor- 
bidity comparing general anaesthesia followed by $i v$ morphine versus combined epidural and general anaesthesia followed by epidural bupivacaine analgesia. However, the average duration of epidural was only $26 \mathrm{hr}$ and subsequent analgesia is not specified.

In summary, there is good evidence that postoperative morbidity in high-risk (ASA 3-4) patients can be reduced by the administration of epidural opioids for postoperative analgesia. The role of epidural local anaesthetics has not been established.

\section{Do epidurals reduce the cost of hospitalization?}

The cost of continuous postoperative epidural analgesia includes the cost of drugs and other consumables, added OR time, and all associated physicians' fees. If hospital policy dictates that patients receiving continuous epidural analgesia are required to be monitored in an ICU or step-down unit, then the added cost may become prohibitive. Although many factors contribute to the cost of hospitalization, the two dominant variables are length of stay and the intensity level of the care provided; to date, few studies have assessed the effect of epidural versus parenteral analgesia on these variables.

Although some studies report a shorter period of tracheal intubation, ${ }^{34}$ length of stay in ICU, ${ }^{30}$ or hospitalization, ${ }^{10}$ only two papers report the actual cost differences. Yeager et al. ${ }^{29}$ (described above) reported a $45 \%$ reduction in the cost of hospitalization and a $26 \%$ reduction in physicians fees in those patients who received postoperative epidural, rather than parenteral, analgesia.

More recently, de Leon-Casasola $e t a^{35}$ have reported similar reductions in the cost of hospitalization. These authors evaluated 462 patients undergoing thoracic or abdominal surgery for cancer. Patients received either epidural analgesia with morphine and bupivacaine $(n=352)$ or iv PCA morphine $(n=100)$ for an average of five days postoperatively. The authors detected no differences in analgesia or outcome, but found a $50 \%$ decrease in the duration of postoperative ventilation and SICU length of stay, and a $35 \%$ reduction in length of stay and overall cost of hospitalization. Although this study was not randomized, demographic data were similar between the two groups, and the large sample size gives the study added credibility.

\section{Conclusions}

Does epidural analgesia offer us anything that we cannot accomplish with parenteral opioids? Specifically, do epidural opioids, with or without local anaesthetics, provide superior analgesia, contribute to reduced morbidity, or reduce the cost of hospitalization? For patients undergoing thoracic, major abdominal, or vascular surgery the answer appears to be yes. Epidural morphine, and prob- ably thoracic epidural fentanyl, can provide analgesia superior to that obtained with $i v$-PCA but the role of epidural opioid local anaesthetic combinations is still unclear. In patients undergoing major vascular surgery, and in those patients scheduled preoperatively for postoperative ICU admission, there is some good evidence that postoperative morbidity is reduced. Finally, there is limited evidence that for patients undergoing major abdominal or thoracic surgery, the cost of hospitalization is reduced, but this important area of research is in its infancy.

\section{References}

\section{Schulman M, Sandler AN, Bradley JW, Young PS,}

Brebner $J$. Postthoracotomy pain and pulmonary function following epidural and systemic morphine. Anesthesiology 1984; 61: 569-75.

2 Miguel $R$, Hubbell $D$. Pain management and spirometry following thoracotomy: a prospective, randomized study of four techniques. J Cardiothorac Vasc Anesth 1993; 7: 529-34.

3 Jayr C, Mollie A, Bourgain JL, et al. Postoperative pulmonary complications: general anesthesia with postoperative parenteral morphine compared with epidural analgesia. Surgery 1988; 104: 57-63.

4 Hjortso NC, Neumann P, Frosig F, et al. Controlled study on the effect of epidural analgesia with local anaesthetics and morphine on morbidity after abdominal surgery. Acta Anesthesiol Scand 1985; 29: 790-6.

5 Cullen $M L$, Staren ED, El-Ganzouri A, Logas WG, Ivankovich $A D$, Economou $S G$. Continuous epidural infusion for analgesia after major abdominal operations: a randomized, prospective, double-blind study. Surgery 1985; 98 : 718-27.

6 Kilbride MJ, Senagore AJ, Mazier WP, Ferguson C, Ufkes, T. Epidural analgesia. Surg Gynecol Obstet 1992; 174: $137-40$.

7 Glass PSA, Estok P, Ginsberg B, Goldberg JS, Sladen $R N$. Use of patient-controlled analgesia to compare the efficacy of epidural to intravenous fentanyl administration. Anesth Analg 1992; 74: 345-51.

8 Loper KA, Ready LB, Downey M, et al. Epidural and intravenous fentanyl infusions are clinically equivalent after knee surgery. Anesth Analg 1990; 70: 72-5.

9 Baxter AD, Laganiere S, Samson B, Stewart J, Hull K, Goernert $L A$. Comparison of lumbar epidural and intravenous fentanyl infusions for post-thoracotomy analgesia. Can J Anaesth 1994; 41: 184-91.

10 Guinard JP, Mourocordatos $P$, Chiolero $R$, Carpenter $R L$. A randomized comparison of intravenous versus lumbar and thoracic epidural fentanyl for analgesia after thoracotomy. Anesthesiology 1992; 77: 1108-15.

11 Sandler AN, Stringer D, Panos $L$, et al. A randomized, double-blind comparison of lumbar epidural and intrave- 
nous fentanyl infusions for postthoracotomy pain relief. Analgesic, pharmacokinetic, and respiratory effects. Anesthesiology 1992; 77: 626-34.

12 Grant RP, Dolman JF, Harper JA, et al. Patientcontrolled lumbar epidural fentanyl compared with patientcontrolled intravenous fentanyl for post-thoracotomy pain. Can J Anaesth 1992; 39: 214-9.

13 Welchew EA, Breen DP. Patient-controlled on-demand epidural fentanyl. A comparison of patient-controlled ondemand fentanyl delivered epidurally or intravenously. Anaesthesia 1991; 46: 438-41.

14 Salomaki TE, Laitinen JO, Nuutinen LS. A randomized double-blind comparison of epidural versus intravenous fentanyl infusion for analgesia after thoracotomy. Anesthesiology 1991; 75: 790-5.

15 Sawchuk CW, Ong B, Unruh HW, Horan TA, Greengrass $R$. Thoracic versus lumbar epidural fentanyl for postthoracotomy pain. Ann Thorac Surg 1993; 55: 1472-6.

16 Benzon HT, Wong HY, Belavic AM, et al. A randomized double-blind comparison of epidural fentanyl infusion versus patient-controlled analgesia with morphine for postthoracotomy pain. Anesth Analg 1993; 76: 316-22.

17 Jayr C, Thomas H, Rey A, Farhat F, Lasser P, Bourgain $J L$. Postoperative pulmonary complications. Epidural analgesia using bupivacaine and opioids versus parenteral opioids. Anesthesiology 1993; 78: 666-76.

18 Moiniche S, Hjortso NC, Blemmer T, Dahl JB, Kehlet $H$. Blood pressure and heart rate during orthostatic stress and walking with continuous postoperative thoracic epidural bupivacaine/morphine. Acta Anaesthesiol Scand 1993; 37 : 65-9.

19 Bisgaard C, Mouridsen P, Dahl JB. Continuous lumbar epidural bupivacaine plus morphine versus epidural morphine after major abdominal surgery. Eur $\mathrm{J}$ Anaesthesiol 1990; 7: 219-25.

20 Dahl JB, Rosenberg J, Hansen BL, Hjortso NC, Kehlet $H$. Differential analgesic effects of low-dose epidural morphine and morphine-bupivacaine at rest and during mobilization after major abdominal surgery. Anesth Analg 1992; 74 : 362-5.

21 Logas WG, El-Baz N, El-Ganzouri A, et al. Continuous thoracic epidural analgesia for postoperative pain relief following thoracotomy: a randomized prospective study. Anesthesiology 1987; 67; 787-91.

22 George KA, Chisakuta AM, Gamble JA, Browne GA. Thoracic epidural infusion for postoperative pain relief following abdominal aortic surgery: bupivacaine, fentanyl or a mixture of both? Anaesthesia 1992; 47: 388-94.

23 George KA, Wright PM, Chisakuta A. Continuous thoracic epidural fentanyl for post-thoracotomy pain relief: with or without bupivacaine? Anaesthesia 1991; 46: 732-6.

24 Badner NH, Bhandari R, Komar WE. Bupivacaine $0.125 \%$ improves continuous postoperative epidural fentanyl analgesia after abdominal or thoracic surgery. Can J Anaesth 1994; 41: 387-92.

25 Badner NH, Komar WE. Bupivacaine $0.1 \%$ does not improve postoperative epidural fentanyl analgesia after abdominal or thoracic surgery. Can J Anaesth 1992; 39: $330-6$.

26 Badner NH, Reimer EJ, Komar WE, Moote CA. Lowdose bupivacaine does not improve postoperative epidural fentanyl analgesia in orthopedic patients. Anesth Analg 1991; 72: 337-41.

27 Cooper DW, Turner G. Patient-controlled extradural analgesia to compare bupivacaine, fentanyl and bupivacaine with fentanyl in the treatment of postoperative pain. $\mathrm{Br} \mathrm{J}$ Anaesth 1993; 70: 503-7.

28 Benzon HT, Wong CA, Wong HY, Brooke C, Wade L. The effect of low dose bupivacaine on postoperative epidural fentanyl analgesia and thromboelastography. Anesth Analg 1994; 79: 911-7.

29 Yeager MP, Glass DD, Neff RK, Brinck-Johnsen T. Epidural anesthesia and analgesia in high-risk surgical patients. Anesthesiology 1987; 66: 729-36.

30 Tuman KJ, McCarthy RJ, March RJ, DeLaria GA, Patel $R V$, Ivankovich $A D$. Effects of epidural anesthesia and analgesia on coagulation and outcome after major vascular surgery. Anesth-Analg 1991; 73: 696-704.

31 Christopherson $R$, Beattie C, Frank SM, et al. Perioperative morbidity in patients randomized to epidural or general anesthesia for lower extremity vascular surgery. Perioperative Ischemia Randomized Anesthesia Trial Study Group. Anesthesiology 1993; 79: 422-34.

32 Baron JF, Bertrand $M$, Barre E, et al. Combined epidural and general anesthesia versus general anesthesia for abdominal aortic surgery. Anesthesiology 1991; 75: 611-8.

33 Davies MJ, Silbert BS, Mooney PJ, Dysart RH, Meads $A C$. Combined epidural and general anaesthesia versus general anaesthesia for abdominal aortic surgery: a prospective randomised trial. Anaesth Intensive Care 1993; 21 : $790-4$.

34 Katz S, Reiten P, Kohl $R$. The use of epidural anesthesia and analgesia in aortic surgery. Am Surg 1992; 58: 470-3.

35 deLeon-Casasola OA, Parker BM, Lema MJ, Groth RI, Orsini-Fuentes $J$. Epidural analgesia versus intravenous patient-controlled analgesia. Reg Anesth 1994; 19: 307-15. 


\section{L'analgésie épidurale postopératoire vaut-elle la peine?}

Richard C. Etches MD FRCPC
Pour certaine catégories de patients, on préconise en postopératoire l'analgésie épidurale aux morphiniques avec ou sans ajout d'anesthésiques locaux. Cependant l'évidence sur laquelle repose cette assertion est vague et incomplete. Cette communication tentera de répondre à la question suivante: l'analgésie épidurale offre-t-elle quelque chose que nous ne pouvons accomplir avec des morphinique par la voie parentérale?

Cette présentation passe en revue la littérature la plus récente portant sur l'analgésie parentérale et épidurale postopératoires chez l'adulte, à l'exclusion de l'obstétrique, au regard de la qualité, des résultats et des coûts hospitaliers. Malheureusement, peu de publications traitent de ces sujets de façon adéquate et il est difficile d'interpréter et de comparer les données pour les raisons suivantes:

1 L'échantillon est trop petit et n'a pas la puissance statistique voulue.

2 La plupart des article s'intéressent à la qualité de l'analgésie et aux effets secondaires associés, mais ne tiennent compte ni de la morbidité ni du coût global de l'hospitalisation.

3 Les comparaisons établies dans ces études sont équivoques parce que les termes " analgésie épidurale » s'adressent souvent à des méthodes différentes. On a recours à des morphiniques à pharmacocinétiques différentes, des anesthésiques locaux avec ou sans morphiniques ajoutés, et de plus en plus fréquemment à des médicaments d'appoint, comme les antiinflammatoires non stéroïdiens (AINS).

4 Les techniques, tout en étant efficaces, peuvent être trop compliquées pour être utilisées quotidiennement.

5 Finalement, peu d'études comparent les techniques épidurales aux alternatives valables disponibles dont "l'analgésie auto-contrôlée intraveineuse " (PCA-IV), utilisée souvent dans un contexte d'analgésie équilibrée avec infiltration locale de la plaie et l'ajout ou non de médicaments comme les AINS.

\section{Revue de la littérature: L'épidurale procure-t-elle une meilleure analgésie?}

\section{La morphine}

Bien que l'usage de la morphine épidurale se soit répandu au début des années 1980, peu d'études ont comparé l'éfficacité de la morphine épidurale avec la morphine parentérale; ces études présentent, par ailleurs, des faiblesses méthodologiques importantes. Malgré tout, on peut affirmer que la morphine épidurale produit une analgésie de meilleure qualité après une thoracotomie et une chirurgie abdominale majeure. Lors d'une étude randomisée et à double aveugle, Schulman et al. ${ }^{1}$ ont comparé l'efficacité de la morphine $5 \mathrm{mg}$ administrée par la voie épidurale et intraveineuse pendant et après une thoracotomie. La drogue était administrée sur demande avec un intervalle minimal de $30 \mathrm{~min}$ entre les doses. Au repos, l'analgésie était de meilleure qualité chez les patients sous épidurale à la morphine pendant les $24 \mathrm{~h}$ de l'étude. Malheureusement, les patients n'avaient reçu à la période opératoire qu'un seule dose de morphine $5 \mathrm{mg}$ administrée avant la chirurgie. Il n'est donc pas suprenant que les patients du groupe im aient souffert de douleurs intense à la période postopératoire immédiate. En comparant la morphine épidurale avec la morphine 2-4 mg iv prn chez une population identique, Miguel et Hubbell ${ }^{2}$ ont rapporté les mêmes résultats.

Deux autres études prospectives, randomisées mais sans masquage, comparant la morphine im à la morphine épidurale rapportent des résultats contradictoires. Jayr $\boldsymbol{e t}$ $a .^{3}$ ont obtenu avec constance une meilleure qualité d'analgésie avec la morphine épidurale uniquement le jour qui suivait l'intervention; cependant la dose de morphine épidurale était très faible, $2 \mathrm{mg}$ q12h. Hjortso et al. ${ }^{4}$ avec une dose de $4 \mathrm{mg}$ q12h ont trouvé l'analgésie (décrite comme l'effet sur la " douleur cumulative " ressentie pendant toute la durée de l'étude) épidurale de meilleure qualité que l'analgésie im à la morphine pendant les trois jours de l'étude; cette étude est discutable parce que la dose de morphine était relativement faible, soit 6-8 mg $\mathrm{q} 4 \mathrm{~h}$, et parce que les patients du groupe épidural avaient reçu de la bupivacaïne $0,5 \% 5 \mathrm{ml} \mathrm{q4h}$ pendant $24 \mathrm{~h}$ après la chirurgie. Cullen et al. ${ }^{5}$ dans une étude randomisée à double insu comparant une perfusion de morphine épidurale aux morphiniques im ont soutenu que la morphine épidurale était supérieure. Cette étude est toutefois faussée par l'insuffisance des doses de morphine im administrées et aussi à cause de la dose limite supérieure de 0,6 $\mathrm{mg} \cdot \mathrm{h}^{-1}$ établie pour la morphine épidurale. 
L'auteur n'a trouvé qu'une étude comparant la morphine épidurale à la morphine au PCA-IV. Kilbride et al. ${ }^{6}$ a réparti au hasard des patients soumis à une chirurgie rectocolique selon qu'il devaient recevoir de la morphine im, au PCA-IV ou en épidurale. Les patients sous morphine épidurale $0,07 \mathrm{mg} \cdot \mathrm{kg}^{-1}$ " sur une base régulière " ont habituellement obtenu une anesthésie supérieure à celle qu'obtenaient ceux qui recevaient de la morphine im ou en PCA-IV sur une période d'étude approximative de cinq jours. Contrairement aux autres études citées, l'utilisation d'un bolus de $2 \mathrm{mg}$ et une perfusion continue de $2 \mathrm{mg} \cdot \mathrm{h}^{-1}$ assurait que le patient recevait une dose parentérale suffisante. La portée de cette étude n'est pas affaiblie par l'utilisation d'un morphinique parentéral contre les percées algiques. Par conséquent, cette étude fournit à date l'évidence la plus convaincante que la morphine épidurale est plus efficace que la morphine parentérale quand les deux sont titrées pour produire l'effet désiré.

\section{Le fentanyl}

On considère la morphine comme le prototype des morphiniques hydrophiles pour usage épidural; c'est la fentanyl qui represente le prototype des agents lipophiles. En partie à cause de la réputation (non prouvée) du fentanyl qui le rendrait moins susceptible de provoquer une dépression respiratoire grave, certains anesthésistes en ont fait leur analgésique de choix.

La plupart des études comparatives portant sur le fentanyl épidural et intraveineux peuvent être regroupées sous trois désignations: l'épidurale lombaire au fentanyl pour la chirurgie abdominale basse ou du membre inférieur; l'épidurale lombaire au fentanyl pour la thoracotomie; l'épidurale thoracique au fentanyl pour la thoracotomie. Dans toutes ces études, il faut porter une attention particulière aux méthodes de titration utilisées pour le fentanyl. Dans plusieurs, on règle le perfusion de fentanyl (épidurale ou intraveineuse) jusqu'à ce que le patient signale sur l'EVA de la douleur un score de 30 ou moins (sur 100). Ces études sont utiles pour démontrer les différences du besoin en fentanyl, mais nétablissent pas de comparaisons appropriées sur l'efficacité analgésique même.

L'utilisation de l'epidurale au fentanyl ne repose pas sur des bases solides. Si on compare le fentanyl épidural au fentanyl $i v$ chez des patients soumis à une chirurgie abdominale basse ou des membres inférieurs, les besoins en fentanyl et les effets secondaires ne diffèrent pas. ${ }^{7.8}$ Après une thoracotomie, les études qui comparent l'analgésie au fentanyl épidural au fentanyl $\dot{w}$ rapportent les même résultats. Baxter et al. ${ }^{9}$ ont comparé pour la thoracotomie l'analgésie au fentanyl épidural lombaire au fentanyl iv avec supplément de morphine en PCA pour compléter l'analgésie: il n'ont pas trouvé de différence sur les scores de douleur ou la quantité supplémentaire de morphine requise. Quand la vitesse d'administration du fentanyl épidural lombaire ou iv est réglée pour obtenir un score de 30/100 sur l'EVA, d'autres études ne rapportent aucune différence concernant l'analgésie et le besoin en fentanyl entre les deux méthodes. ${ }^{10,11}$ En comparant l'analgésie au fentanyl épidural lombaire au fentanyl $i v$, Grant et al. ${ }^{12}$ n'ont pas trouvé de différence pour l'analgésie mais ont rapporté une baisse modeste (28\%) des besoins en fentanyl dans le groupe épidural.

Après une thoracotomie ou une chirurgie abdominale haute, l'efficacité de l'épidurale thoracique au fentanyl demeure incertaine. Welchew et Breen ${ }^{13}$ ont comparé le fentanyl épidural administré par PCA grâce à un cathéter situé à $\mathrm{D}_{7}-\mathrm{D}_{8}$ avec le fentanyl $\dot{i}$ pour une chirurgie $\mathrm{ab}-$ dominale haute; ils ont trouvé une réduction de $50 \%$ du besoin en fentanyl mais aucune différence sur les scores de douleur. Salomaki et al. ${ }^{14}$ ont rapporté des résultats identiques après la thoracotomie avec une perfusion épidurale de fentanyl à $\mathrm{D}_{4}-\mathrm{D}_{5}$; l'analgésie était comparable avec une réduction de $43 \%$ du besoin en fentanyl. D'autres n'ont pas trouvé de différence entre les scores de douleur ni de réduction valable du besoin en fentanyl lorsquils ont comparé l'épidurale thoracique à la lombaire ou au fentanyl $\dot{w} ;{ }^{10,16}$ il est difficile de concilier ces résultats avec ceux déjà cités. Contrairement aux articles précédents, Benzon et al..$^{16}$ ont montré une analgésie de meilleure qualité, surtout pendant la toux, après la thoracotomie sous anesthésie épidurale thoracique au fentanyl comparativement à la PCA à la morphine. Il est aussi difficile d'expliquer pourquoi le fentanyl en épidurale thoracique pourrait être supérieur à la PCA-IV à la morphine mais pas au fentanyl $i v$. On ne sait pas non plus pourquoi certains articles, mais pas tous, ont rapporté une réduction de la dose de fentanyl requise lorsqu'il était administré par voie épidurale thoracique comparativement à la voie intraveineuse. Même si la qualité de l'analgésie est identique, lincidence et lintensité des effets secondaires dont les nausées et vomissements, ${ }^{10,13,14}$ la sédation, ${ }^{10,14-16}$ et la dépression respiratoire ${ }^{15}$ peuvent être atténués quand le fentanyl est administré par la voie épidurale.

\section{Rôle de la bupivacaine}

Les morphiniques seuls peuvent procurer une excellente analgésie mais ils sont associés à une incidence élevée d'effets indésirables. D'autre part, les anesthésiques locaux peuvent produire une analgésie complète, mais génèrent une incidence inacceptable de bloc sensitif, moteur et autonome. L'association de basses concentrations de bupivacaïne à des morphiniques épiduraux a pour objectif de minimiser les effets indésirables des deux agents tout en maintenant la meilleur analgésie possible. Tou- 
tefois, l’évidence recueillie jusqu'à maintenant ne permet pas de conclure en ce sens.

Lorsque comparée à la morphine parentérale, la morphine épidurale thoracique $\left(D_{7}-D_{11}\right) 0,25 \mathrm{mg} \cdot \mathrm{h}^{-1}$ avec bupivacaïne $0,125 \% 10 \mathrm{ml} \cdot \mathrm{h}^{-1}$ a produit une meilleure analgésie pendant au moins $48 \mathrm{~h}$ après une chirurgie abdominale majeure. Cependant, sept des 78 patients présentaient un bloc moteur le premier jour suivant l'intervention. ${ }^{17}$ Moiniche et al. ${ }^{18}$ ont rapporté des résultats semblables avec la morphine $0,2 \mathrm{ml} \cdot \mathrm{h}^{-1}$ associée à la bupivacaine $0,25 \% 4 \mathrm{ml} \cdot \mathrm{h}^{-1}$ chez les patients soumis à une cholécystectomie ouverte par minilaparoscopie; les scores de douleur au repos et à l'activité étaient plus bas $24 \mathrm{~h}$ après la chirurgie, mais ne l'étaient plus après 48 h. Contrairement à l'étude précédente, aucun des patient n'a présenté de bloc sensitif ou moteur décelable à 24 h.

Comparativement à la morphine seule, l'association péridurale bupivacaïne-morphine peut procurer une meilleure analgésie. A la suite d'une chirurgie abdominale majeure, Bisgaard et al. ${ }^{19}$ ont administré soit de la morphine épidurale 4-6 mg q6-8h soit de la morphine 0,54 $\mathrm{ml} \cdot \mathrm{h}^{-1}$ plus bupivacaïne $0,25 \% 9 \mathrm{ml} \cdot \mathrm{h}^{-1}$. L'analgésie a été supérieure chez les patients qui recevaient morphinebupivacaïne pendant les 16 premières heures suivant la chirurgie, mais ces différences disparaissaient à la $24 \mathrm{e}$ $\mathrm{h}$, avec des scores de douleur très bas dans les deux groupes. Malheureusement les auteurs ne mentionnent pas l'incidence de bloc sensitif ou moteur. Dans une étude identique, Dahl et al. ${ }^{20}$ ont comparé la morphine épidurale $0,2 \mathrm{ml} \cdot \mathrm{h}^{-1}$ avec ou sans bupivacaïne $0,25 \% 4$ $\mathrm{ml} \cdot \mathrm{h}^{-1}$. Tous les patients ont reçu du piroxicam avant et après lintervention et de la morphine $i v$ ou im au besoin. Les patients qui avaient reçu le mélange morphine-bupivacaīne ont rapporté, au repos et à l'action, des scores de douleur plus bas pour les premières $30 \mathrm{~h}$ après la chirurgie, mais non à $48 \mathrm{~h}$. Tous les patients sous bupivacaïne ont rapporté une bloc sensitif $48 \mathrm{~h}$ après l'intervention mais aucun n'a rapporté de bloc moteur $12 \mathrm{~h}$ après l'intervention. Par contre, Logas et al., dans une étude à l'aveugle, randomisée et prospective n'ont pas trouvé après la thoracotomie d'avantage à l'ajout de bupivacaïne $0,1 \%$ en épidurale thoracique à la morphine $0,1 \%$. Cependant, dans les deux groupes l'analgésie était meilleure qu'avec la morphine im.

Pour le fentanyl avec de la bupivacainne 0,125\%-0,25\% comparé au fentanyl seul les données sont aussi peu convaincantes. Plusieurs études montrent une réduction modeste du score de la douleur et du besoin de fentanyl épidural supplémentaire ou des morphiniques parentéraux pendant les $24 \mathrm{~h}$ qui suivent la chirurgie, mais ces différences n'apparaissent plus après la première journée postopératoire. En comparant, après une chirur- gie de l'aorte, le fentanyl épidural thoracique $10 \mu \mathrm{g} \cdot \mathrm{ml}^{-1}$ avec ou sans bupivacaïne $0,2 \%$, George et al. ${ }^{22}$ ont montré une baisse de $11 \%$ de la consommation en fentanyl et des. scores de douleur moins élevés parmi les patients recevant de la bupivacaine. Un des dix patients sous fentanyl-bupivacaïne s'est plaint de faiblesse aux membres. Comme cette étude n'a duré que $24 \mathrm{~h}$ après lintervention, on ne sait pas si les différences analgésiques se sont prolongées. Avec un protocole identique, après une thoracotomie, le même groupe a montré avec l'ajout de bupivacaïne la supériorité de l'analgésie pour les premières $18 \mathrm{~h}$, mais non 24 à $48 \mathrm{~h}$ après lintervention. Comme dans l'étude précédente, un patient sur dix a présenté de la faiblesse musculaire aux membres inférieurs. ${ }^{23}$

Badner et al. ${ }^{24,25}$ ont rapporté que l'addition de bupivacaïne à $0,125 \%$, mais non à $0,1 \%$, au fentanyl épidural améliorait l'anesthésie pendant $48 \mathrm{~h}$ après la chirurgie. Les besoins en fentanyl n'ont pas différé entre les deux groupes. Cependant la différence entre les scores de douleur était plus élevée en salle de réveil; ceci s'explique, en partie du moins, par le fait que les patients au mélange fentanyl-bupivacaïne avaient reçu deux fois plus de bupivacaine pendant lintervention. Si on exclut de l'analyse les scores de douleur de la salle de réveil, il n'y a plus de différence entre les groupes. De plus, parmi les patients qui avaient reçu bupivacaïne $0,125 \%$, quatre ont développé de la faiblesse et trois présentaient des zones d'insensibilité.

Après une chirurgie orthopédique, l'ajout de bupivacaïne $0,1 \%$ au fentanyl épidural n'a pas amélioré l'analgésie ou réduit les besoins en fentanyl. ${ }^{26} \mathrm{Par}$ contre, l'ajout de bupivacaïne $0,125 \%$ au fentanyl épidural $5 \mu \mathrm{g} \cdot \mathrm{ml}^{-1}$ en PCA a réduit les besoin en fentanyl de $24 \%$; ici encore, les scores de douleur étaient identiques entre les groupes. Cependant, l'effet d'épargne a été contrebalancé par une augmentation de lincidence (48\%) d'hypotension. ${ }^{27}$

Plus récemment, dans une étude bien contrôlée, randomisée et à double aveugle, Benzon et al ${ }^{28}$ ont comparé le fentanyl $10 \mu \mathrm{g} \cdot \mathrm{ml}^{-1}$ seul, ou avec bupivacaïne $0,1 \%$, $0,15 \%$ et $0,2 \%$ chez des patients soumis à une chirurgie abdominale ou génito-urinaire majeure. Les auteurs n'ont pas trouvé l'analgésie différente au repos ou pendant la toux et pas de différence non plus sur la consommation de fentanyl. Plus de patients du groupe bupivacaine ont présenté une perte de sensibilité; par ailleurs, les effets secondaires étaient identiques dans les deux groupes.

Il est difficile d'expliquer la divergence des résultats, spécialement avec le fentanyl épidural, seul ou en association avec de la bupivacaïne, mais plusieurs facteurs pourraient intervenir. D'abord, peu d'études permettent aux patients d'adapter à leurs besoins la dose du médicament épidural. Le plus souvent, linvestigateur installe une perfusion fixe ou titrée selon une score d'EVA 
prédéterminé, ordinairement $3 / 10$ ou moins. Deuxièmement, le fentanyl, avec ou sans bupivacaïne, pourrait être plus efficace lorsqu'il est utilisé pour soulager la douleur provoquée par une incision située au niveau d'un métamère particulier (par ex., une incision sous-costale ou thoracique vs une incision abdominale verticale ou abdominopérinéale). Finalement, peu d'études établissent une corrélation entre les scores de douleur et l'activité; ceux-ci pourraient être plus importants que les scores de douleur au repos.

Pour résumer, des études réalisées au cours des dix dernières années confirment que la morphine épidurale procure une meilleure analgésie que celle qu'on obtient avec la voie im ou en PCA-IV après une chirurgie abdominale majeure ou thoracique. Pour le fentanyl, la preuve n'est pas convaincante. Cependant, il est clair que si on choisit le fentanyl épidural, l'epidurale devrait être installée au même niveau métamérique que la chirurgie. Pour l'épidurale au féntanyl ou à la morphine, l'ajout de bupivacaïne $0,125 \%-0,25 \%$ peut améliorer l'analgésie et diminuer les besoins de morphiniques pendant les $24 \mathrm{~h}$ qui suivent l'intervention. Après cette période, peu de données justifient son utilisation. L'ajout de bupivacaïne $0,1 \%-0,25 \%$ aux morphiniques épiduraux provoque chez certains patients un bloc moteur, sensitif et autonome indésirable. Ces effets sont sérieux sils limitent la mobilité, masquent la symptomatologie ou provoquent une hypovolémie relative avec de l'hypotension et une chute du débit urinaire.

\section{L'épidurale a-t-elle une influence sur le devenir du patient?}

On s'entend généralement sur le fait que les morphiniques épiduraux avec ou sans bupivacaïne peuvent procurer une analgésie aussi bonne et souvent meilleure que les morphiniques administrés par la voie parentérale seuls. On est toutefois moins d'accord lorsqu'il s'agit de confirmer que les morphiniques épiduraux ont une influence favorable sur le devenir du patient. Cette absence de consensus est due en grande partie aux limites imposées par les protocoles d'études. Plusieurs études comparant les morphiniques parentéraux aux morphiniques épiduraux sont de courte durée, ordinairement de $24-48$ h et insistent surtout sur l'analgésie et le besoin en morphiniques. Certaines études imposent une dose fixe de morphinique épidural avec des doses parentérales pour supplémenter l'analgésie. Peu d'études permettent au patient de déterminer lui-même la dose épidurale de morphinique: plus fréquemment, le chercheur règle la perfusion de morphinique pour obtenir une score sur l'EVA de $3 / 10$ ou moins. De plus, peu d'études portent sur les populations à risque. Si on regarde de plus près les études qui s'adressent à ces préoccupations, l'évidence en faveur de l'analgésie épidurale prend beaucoup plus de poids.

Trois études randomisées et prospectives montrent les effets bénéfiques de l'anesthésie épidurale après une chirurgie majeure. Dans un article important, Yeager et al. ${ }^{29}$ ont réparti au hasard des patients à haut risque (définis comme patients programmés en préopératoire pour un séjour à l'unité des soins intensifs en postopératoire) pour recevoir soit une anesthésie générale avec des morphiniques parentéraux en postopératoire, soit une anesthésie épidurale associée à une anesthésie générale " légère " suivie d'une épidurale aux anesthésiques locaux avec ou sans morphinique. Cette étude fut arrêtée après seulement 53 patients à cause de lincidence beaucoup moins élevée de morbidité cardiovasculaire, d'infections sérieuses et, en général, de complications moindres. Le taux de mortalité était aussi moins élevé parmi les patients sous épidurale, mais à cause de la petite dimension de l'échantillon, les auteurs ont choisi de ne pas insister sur ce dernier point.

Tuman et al.$^{30}$ ont depuis répété l'étude de Yaeger avec une méthodologie identique chez 80 patients soumis à une chirurgie vasculaire infrainguinale $(55 \%)$ et aortoiliaque (45\%). Les patients du groupe épidural étaient plus âgés et avaient des d'antécédents de diabète et d'infarctus du myocarde plus importants. Chez les patients choisis pour recevoir l'épidurale, l'incidence préopératoire de plusieurs autres variables, dont les antécédents angineux, l'insuffisance cardiaque et l'infection était plus élevée mais non de façon significative. Comme dans l'étude de Yeager, Tuman et al. ont trouvé un taux de complications moins élevé, en particulier de complications cardiovasculaires et infectieuses et moins d'occlusions du greffon. L'incidence des complications neurologique et le nombre dintubations prolongées était aussi moins élevée, voisine de la signification statistique dans le groupe épidural. En utilisant une analyse de régression logique, les seuls prédicteurs de complications cardiovasculaires étaient l'antécédent d'insuffisance cardiaque et l'anesthésie générale sans épidurale. Lincidence plus élevée d'occlusion de greffon rapportée dans cette étude concorde avec une autre étude réalisée chez des patients soumis à une chirurgie vasculaire infrainguinale, soit sous anesthésie générale et analgésie parentérale, soit sous anesthésie et analgésie épidurales, celle-ci maintenue pendant environ $48 \mathrm{~h}$ après l'intervention. ${ }^{31}$

A partir des études déjà mentionnées, il est possible que les différences de morbidité aient été causées par la technique anesthésique, plutôt que par l'analgésie postopératoire. Pour élucider cette question, Baron et al ${ }^{32}$ ont étudié 173 patients programmés pour une chirurgie de l'aorte abdominale. Les patients ont été assignés au hasard pour recevoir soit une anesthésie générale seule, soit une anesthésie épidurale à $D_{8}-D_{9}$ associée à une 
anesthésie générale légère. Après lintervention, les patients des deux groupes ont reçu de la morphine $s c$, de la bupivacaïne épidurale ou du fentanyl épidural. Les patients sous anesthésie épidurale ont été extubés plus rapidement (cinq heures vs huit heures) après la chirurgie, mais les résultats n'ont pas été différents pour le reste. Les auteurs ont conclu que l'association anesthésie générale-épidurale ne présente pas d'avantages évidents sur l'anesthésie générale seule, et que l'analgésie postopératoire, plutôt que la gestion périopératoire, pouvait être le facteur déterminant de l'évolution.

Contrairement aux étude de Yeager et Tuman, Hjortso et al. ${ }^{4}$ n'ont pas trouvé de différence sur le devenir de 100 patients soumis à une chirurgie vasculaire et thoracique, mais contrairement aux étude de Yeager et Tuman, lincidence des antécédents cardiovasculaires et respiratoires était basse, tous les patients étant de classe ASA 1 et 2. D'autres études qui portent à croire l'absence de bénéfice pour l'analgésie épidurale ont une méthodologie limitée, en particulier en ce qui concerne la dose et la durée de l'analgésie épidurale morphinique. Jayr $e t$ al. ${ }^{3,17}$ n'ont pas démontré d'avantages pour l'analgésie épidurale après une chirurgie majeure non vasculaire; $c e-$ pendant, les patients recevaient des doses fixes et relativement faibles de morphine épidurale $(0,2-0,25$ $\left.\mathrm{mg} \cdot \mathrm{h}^{-1}\right)$. Lors d'une étude groupant 50 patients soumis à une chirurgie abdominale aortique, Davies et al. ${ }^{33}$ n'ont pas trouvé de différence de morbidité postopératoire lorsqu'ils ont comparé l'anesthésie générale suivie de morphine iv à l'anesthésie générale suivie d'une analgésie épidurale. Cependant, la durée moyenne de l'analgésie épidurale n'était que de $26 \mathrm{~h}$ et l'analgésie subséquente n'était pas spécifiée.

En résumé, les données réceuillies permettent d'affirmer que la morbidité postopératoire chez les patients à risque élevé (ASA 3 et 4) peut être diminuée par l'administration épidurale de morphiniques pour l'analgésie postopératoire. Le rôle de l'épidurale aux anesthésiques locaux n’a pas été établi.

L'épidurale diminue-t-elle les coûts de lhospitalisation? Le coût de l'épidurale continue pour l'analgésie comprend le coût des drogues et autres fournitures, le temps d'utilisation des salles d'opération et les honoraires professionnels. Si la politique de lhôpital dicte que les patients sous analgésie épidurale doivent être monitorisés à l'USI ou en unité spéciale, les coûts peuvent s'avérer prohibitifs. Bien que plusieurs facteurs contribuent aux coûts de l'hospitalisation, les deux variables les plus importantes sont la longueur du séjour hospitalier et l'importance des soins requis; jusqu'à maintenant peu d'études ont évalué les effets sur ces variables de l'analgésie épidurale comparativement à l'analgésie parentérale.
Bien que certaines études rapportent une période d'intubation abrégée, ${ }^{34}$ les durées de séjour aux soins intensifs, ${ }^{30}$ ou en chambre à l'hôpital ${ }^{10}$ plus courts, seulement deux articles font état d'une différence de coûts. Yeager et al. ${ }^{29}$ (voir plus haut) ont rapporté une baisse de $45 \%$ du coût d'hospitalisation et de $26 \%$ des honoraires des médecins chez les patients qui avaient reçu une épidurale postopératoire, plutôt qu'une analgésie parentérale.

Plus récemment, de Leon-Casasola et al. ${ }^{35}$ ont décrit des réductions semblables sur le coût d'hospitalisation. Ces auteurs ont évalué 462 patients soumis à une chirurgie thoracique ou abdominale pour cancer. Les patients ont reçu soit une analgésie épidurale à la morphine et à la bupivacaïne $(n=352)$ soit de la morphine en PCA-IV $(n=100)$ pour une durée moyenne de cinq jours en postopératoire. Les auteurs n'ont pas décelé de différence sur l'analgésie et les résultats, mais ont trouvé une diminution de $50 \%$ de la durée de la ventilation postopératoire et de la durée de séjour à l'USI, et une réduction de 35\% du séjour hospitalier et des coût globaux générés par l'hospitalisation. Bien que cette étude n'ait pas été randomisée, les données démographiques étaient identiques entre les deux groupes et limportance numérique de l'échantillon ajoute à la crédibilité de l'étude.

\section{Conclusions}

L'épidurale nous offre-t-elle quelque chose que nous ne pouvons accomplir avec les morphiniques parentéraux? Plus spécifiquement, est-ce que les morphiniques épiduraux, avec ou sans anésthésiques locaux, procurent une meilleure analgésie, contribuent à réduire la morbidité, et réduisent les coûts d'hospitalisation? Pour la chirurgie thoracique, abdominale majeure et vasculaire, il semble que la réponse soit oui. La morphine épidurale, et, vraisemblablement, le fentanyl épidural thoracique, peuvent procurer une analgésie supérieure à celle de la PCAIV, mais, toutefois, le rôle de la combinaison épidurale morphinique-anesthésique local demeure vague. Chez les patients qui subissent une chirurgie vasculaire majeure, et ceux qui sont programmés en préopératoire pour une admission postopératoire à l'USI, une certaine évidence permet de croire que la morbidité postopératoire est réduite. Finalement, on ne peut affirmer avec certitude que pour les patients soumis à une chirurgie abdominale majeure ou thoracique, le coût de l'hospitalisation soit réduit. Dans ces domaines importants, le recherche ne fait que débuter.

\section{Références}

(Voir page R24) 